\author{
Юрий Степанович Кучуривский \\ https://orcid.org/0000-0003-0007-8636 \\ преподаватель кафедры хорового дирижирования \\ Одесской национальной музыкальной академии \\ имени А. В. Неждановой \\ yskuchurivskyy@ukr.net

\section{ЖАНРОВАЯ СТИЛИСТИКА РЕКВИЕМОВ ДЖ. РАТТЕРА, Б. ЧИЛКОТТА И ДЖ. ТАВЕНЕРА В КОНТЕКСТЕ ТРАДИЦИЙ АНГЛИЙСКОЙ ХОРОВОЙ МУЗЫКИ}

\begin{abstract}
Цель статьи - обсуждение специфических особенностей жанровой стилистики образцов заупокойной мессы, представленных в творчестве современных композиторов Великобритании. Методология. В исследовании использованы культурологический и музыкально-исторический подходы к изучению музыкального искусства, позволяющие рассматривать жанр реквиема в широком контексте английской культуры. Методологические установки музыкальной культурологии дают возможность определения "ситуативного комплекса», закрепленного за реквиемом как жанром литургической музыки в католической и англиканской традициях. Музыковедческий метод жанрово-стилевого анализа направлен на определение специфических черт индивидуального композиторского преломления жсанрового стиля реквиема в творчестве современных представителей английской хоровой музыки и его связей с национальной традицией. Научная новизна. В украинском музыковедении вопросы исторического развития и национальной специфики английской хоровой культуры до сих пор не становились объектом исследовательского интереса. Реквиемы британских композиторов ХХ века востребованы в современной исполнительской практике, и поэтому их изучение заполнит существенные пробелы как в музыковедческих разработках, так и в исполнительском осмыслении хорового репертуара. Выводы. В реквиемах современных британских композиторов представлены различные варианты интерпретации канонической модели латинского реквиема, которые в значительной мере «обогащены» элементами национальной хоровой традиции, связанной со стилистикой богослужебной практики англиканства (Дж. Раттер и Б. Чилкотт). Также на развитие жанра реквиема в творчестве английских композиторов современности повлияли восточно-христианские религиозные идеи православия, оригинально преломленные Дж. Тавенером. В иелом жанровая стилистика реквиемов указанных композиторов опирается на структурную модель латинского реквиема, хоровой стиль англикан-
\end{abstract}

(C) Кучуривский Ю. С., 2017 
ского пения и эстетику «новой простоты», актуальную для музыкального искусства современности.

Ключевые слова: жанр, жанровая стилистика, национальная традиция, хоровая музыка, реквием, англиканское пение.

Kuchurivsky Yriy, the teacher of The Odessa National A. V. Nezhdanova Academy of Music, the department of the choral conducting

Genre stylistics of requiems by J. Rutter, B. Chilcott and J. Tavener in the context of the traditions of English choral music

The purpose of the article is to discuss specific features of the genre stylistics of the samples of the funeral mass presented in the works of contemporary composers of Great Britain. Methodology. The study used cultural and musical-historical approaches to the study of musical art, allowing us to consider the genre of the requiem in the broad context of English culture. The methodological guidelines of musical culturology make it possible to define the «situational complex» fixed for the requiem as a genre of liturgical music in the Catholic and Anglican traditions. The musicological method of genre-style analysis is aimed at determining the specific features of the individual composer's refraction of the genre style of the requiem in the works of contemporary representatives of English choral music and its connections with the national tradition. Scientific novelty. In Ukrainian musicology, the questions of the historical development and the national specifics of the Anglican choral culture have not been specifically the object of research interest so far. The requisites of British composers of the twentieth century are in demand in modern performing practice, and therefore their study will fill in significant gaps in both musicological studies and in performing comprehension of the choral repertoire. Conclusions. In requiems of contemporary British composers, various versions of the interpretation of the canonical model of the Latin requiem are presented, which are largely enriched with elements of the national choral tradition associated with the stylistics of the liturgical practice of Anglicanism (J. Rutter and B. Chilcott). Also, the development of the requiem genre in the work of contemporary British composers was influenced by the Eastern Christian religious ideas of Orthodoxy, originally refracted by J. Tavener. In general, the genre style of the requiems of these composers is based on the structural model of the Latin Requiem, the choral style of Anglican singing and the aesthetics of the "new simplicity» that is relevant to the contemporary musical art.

Keywords: genre, genre stylistics, national tradition, choral music, requiem, Anglican singing. 
Кучурівський Юрій Степанович, викладач кафедри хорового диригування Одеської національної музичної академі імені А. В. Нежданової

Жанрова стилістика реквієму Дж. Раттера, Б. Чілкотта і Дж. Тавенера в контексті традицій англійської хорової музики

Мета статmі - обговорення специфічних особливостей жанрової стилістики зразків заупокійної меси, представлених у творчості сучасних композиторів Великобританії. Методологія. У дослідженні використані культурологічний і музично-історичний підходи до вивчення музичного мистецтва, що дозволяють розглядати жанр реквієму в широкому контексті англійської культури. Методологічні установки музичної культурології дають можливість визначення «ситуативного комплексу», закріпленого за реквіємом як жанром літургійної музики в католицькій $і$ англіканській традиції. Музикознавчий метод жканровостильового аналізу спрямований на визначення специфічних рис індивідуального композиторського заломлення жанрового стилю реквієму в творчості сучасних представників англійської хорової музики і його зв'язків з національною традицією. Наукова новизна. В українському музикознавстві питання історичного розвитку і національної специфіки англійської хорової культури не ставали об'єктом дослідницького інтересу. Реквієми британських композиторів ХХ століття затребувані в сучасній виконавській практиці, і тому їх вивчення заповнить істотні прогалини як в музикознавчих розробках, так і у виконавському осмисленні хорового репертуару. Висновки. Реквієми сучасних британських композиторів представляють різні варіанти інтерпретації канонічної моделі латинського реквієму, які в значній мірі «збагачені» елементами національної хорової традицї, пов'язаної зі стилістикою богослужбової практики англіканства (Дж. Раттер і Б. Чілкотт). Також на розвиток жанру реквієму в творчості англійських композиторів сучасності вплинули східно-християнські релігійні ідеї православ'я, оригінально заломлені Дж. Тавенером. В цілому жанрова стилістика реквіємів зазначених композиторів спирається на структурну модель латинського реквієму, хоровий стиль англіканського співу і естетику «нової простоти», актуальну для музичного мистецтва сучасності.

Ключові слова: жсанр, жанрова стилістика, національна традиція, хорова музика, реквієм, англіканський спів.

Актуальность темы. Хоровые реквиемы, созданные современными композиторами Великобритании, вносят значительный вклад в современную европейскую музыку академической традиции. Сочинения таких выдающихся авторов как Б. Бриттен и Э. Л. Уэббер, Дж. Раттер и Дж. Тавенер, К. Дженкис и Б. Чилкотт прочно закрепились в исполнительской практике, некоторые из них востребованы в качестве учебного репертуара, все чаще хоровая музыка этих ком- 
позиторов звучит и в Украине. Однако, при всей очевидной востребованности в исполнительской практике, жанрово-стилистические аспекты индивидуальных композиторских трактовок жанра заупокойной мессы - до сих пор не становились предметом специального музыковедческого исследования. В частности проблема национального своеобразия жанра реквиема, представленного в хоровом наследии британских композиторов современности, и его связей с национальной английской музыкальной традицией практически не обсуждалась.

Научная новизна. В украинском музыковедении вопросы исторического развития и национальной специфики английской хоровой культуры до сих пор не становились объектом исследовательского интереса. Заупокойные мессы современных британских композиторов рассматриваются, с одной стороны, с позиций наследования национальных традиций английской профессиональной и богослужебной музыки, с другой - в контексте специфики индивидуальной творческой трактовки жанровой модели реквиема отдельно взятым композитором.

Цель статьи - обсуждение специфических особенностей жанровой стилистики образцов заупокойной мессы, представленных в творчестве современных композиторов Великобритании. Объект исследования - английская хоровая музыка XX века. Предмет исследования - жанровая стилистика реквиемов в творчестве современных британских композиторов.

Анализ исследований и публикаций. На сегодняшний день наиболее специальными исследованиями в области английской хоровой культуры являются работы Л. Г. Ковнацкой, которая до сих пор является самым крупным русскоязычным специалистом в области музыкальной культуры Англии: сведения о хоровых сочинениях композиторов XX века содержатся в ее монографии и отдельных статьях [4]. Исторический контекст становления профессионального английского хорового искусства и его литургических истоков освещен в фундаментальном труде Э. Уилсона-Диксона «История христианской музыки» [6]. При этом судьба заупокойной мессы не обсуждается этим автором в контексте основных принципов реформирования богослужебной практики в англиканской церкви. Соответственно не затрагиваются и сочинения в этом жанре современных английских композиторов, оставляя открытым вопрос о причинах такого живого интереса представителей национальной хоровой традиции к жанру реквиема. Раз- 
розненная информация о реквиемах композиторов Великобритании второй половины XX - начала XXI века содерится в малочисленных статьях, посвященных творчеству того или иного автора [2], а также в аннотациях к аудиозаписям и концертам.

Основное содержание. Среди композиторов Великобритании XX века, обращавшихся к хоровым литургическим жанрам, наиболее полно изучено лишь творчество Б. Бриттена (1913-1976) - классика английской музыки, чей «Военный реквием» вошел в сокровищницу европейского музыкального искусства. Исследование вопросов связей стиля Б. Бриттена с национальными традициями вокальнохорового искусства наиболее фундаментально представлено в работах Л. Г. Ковнацкой. Однако имена следующих за Бриттеном композиторов - нового поколения, активно работающего с жанром реквиема - до сих пор остаются «в тени» их великого предшественника. И это вполне можно объяснить общепризнанным статусом классика XX века, закрепившимся за реквиемом Б. Бриттена, и не совсем полным представлением современных украинских музыкантов о сочинениях таких авторов как Дж. Раттер, Дж. Тавенер, Б. Чилкотт, которые в западноевропейском музыкальном мире завоевали признание и статус крупнейших мастеров хорового искусства.

Примечательно, что к реквиему в своем творчестве обращаются все перечисленны композиторы, заупокойная месса стала тем жанром, который отвечал творческим установкам британских композиторов на рубеже $\mathrm{XX}-\mathrm{XXI}$ веков и мировоззренческим и эстетическим представлениям. И это не случайно: большинством историков и теоретиков музыкального искусства признается факт, что тот или иной музыкальный жанр изначально связан с конкретной жизненной ситуацией, с конкретным жизненным контекстом, определившем его функцию и назначение в жизни человека, он - социально обусловлен. Именно поэтому музыковеды определяют жанр как «жизненную ось» музыки [7, 218], «генетическую структуру», отражающую конкретный «ситуативный комплекс» [5]. Мемориальный смысл реквиема, закрепленный за «ситуативным комплексом», его породившим, во многом отвечал трагическим событиям в истории современности (военные и государственно-политические, конфессиональные конфликты, экологические катастрофы и т. п.). Но также он оказался созвучен все более возрастающей в условиях глобализации потребности человека в духовных основаниях бытия, необходимостью опыта переживания трансцендентного, что выра- 
зилось в феномене так называемой «новой сакральности» в музыкальном искусстве последней трети XX - первых десятилетий XXI столетия. Момент «проживания» смерти, даже если он предельно субъективен и связан исключительно с личностным переживанием утраты близкого человека, становился стимулом для объективного авторского выражения своего религиозного сознания или же личностного отношения к культурным традициям.

Обращение к заупокойной мессе британских композиторов-современников большей частью было связано именно с субъективным фактором, но каждый из образцов этого жанра стал высокохудожественным воплощением проблемы Жизни и Смерти, актуальной для всех исторических эпох. В каждом из них представлена индивидуальная трактовка жанровой модели реквиема, сложившейся в христианской богослужебной традиции, и обнаруживаются связи с национальными истоками жанровой стилистики произведения.

Так, например, Боб Чилкотт (род. 1955), представляющий среднее поколение современных композиторов Великобритании, в своем Реквиеме (2010) обобщает многовековые традиции английской хоровой музыки и римо-католической богослужебной музыки, идя по пути соединения структуры классического латинского реквиема со стилистикой англиканского пения. Творческая индивидуальность Чилкотта (композитор, дирижер, певец) складывалась в среде исполнительской хоровой традиции: он долгое время был тенором в хоре Королевского колледжа, а также в течение 12 лет был в составе «King's Singers». «King's Singers» - британский вокальный ансамбль а cappella, основанный в 1968 году шестью певчими хора Королевского колледжа и названный в его честь. В Великобритании их популярность достигла своего пика в 1970-х и начале 1980-х годов.

Исполнительский состав Реквиема Чилкотта явно наследует традиции исполнения богослужебной музыки в Королевской капелле еще со времен Реформации: это касается использования органа и ансамбля деревянных духовых инструментов (см. об этом у Э. УилсонаДиксона [6]), а также приоритета тенора в солирующей партии. Написанное для хора, сопрано, тенора и оркестра, это сочинение также существует и в версии с камерным ансамблем духовых, но обязательно с участием органа.

В своем сочинении сам композитор отмечает влияние Реквиема Г. Форе, который в определенной мере вдохновил его на создание этой работы и был главным ориентиром в его индивидуальном под- 
ходе к трактовке заупокойной мессы. Это влияние большинство критиков связывают, прежде всего, с мелодическим стилем сочинения английского автора - как хоровые, так и сольные фрагменты Реквиема отличаются мелодической красотой и даже некоторой изысканностью, но при этом просты и доступны для восприятия. Простота и ясность мелодий - в этом также сходятся авторы большинства рецензий на данное произведение.

Семичастную композицию Реквиема Чилкотта (по подобию Г. Форе) образуют традиционные части латинского реквиема, которые поются на латинском языке. Так же, как и в Реквиеме Г. Форе, главной особенностью у Чилкотта является отсутствие «Dies irae»той части латинского реквиема, которая стала своеобразным жанровым «маркером» в музыке XIX-XX столетий, указывающим на смысл художественного воплощения (предельно драматического) темы смерти в европейской музыкальной традиции. Как известно, именно образы Страшного суда вызывали к жизни яркие и экспрессивные фрагменты классических реквиемов указанного исторического периода - драматургических центров и кульминаций масштабных и сложных сочинений. У Чилкотта сохранен только раздел «Ріu Jesus», содержание которого связано с молитвой о даровании покоя усопшим и лишено всяческих «страстей» - эта часть Реквиема является центром композиции вслед за известнейшим «молитвенным» соло сопрано в сочинении Г. Форе.

Единственная часть Реквиема Б. Чилкотта (№ 6) исполняется только хором и на английском языке, воспроизводя образ англиканского обряда погребения - это одна из молитв из «Книги общих молитв» («Ибо Он знает тайны сердца. Но за Тебя умерщвляют нас всякий день, считают нас за овец, обреченных на заклание. Восстань, что спишь, Господи! пробудись, не отринь навсегда. Для чего скрываешь лице Твое, забываешь скорбь нашу и угнетение наше? ибо душа наша унижена до праха, утроба наша прильнула к земле. Восстань на помощь нам и избавь нас ради милости Твоей»; Псалом 43). Этот номер выступает ярким контрастом к латинским частям мессы и может также расцениваться в качестве кульминационного.

Исключение «Dies irae» из общей структуры заупокойной мессы в данном случае можно объяснить, с одной стороны, «подражанием» Г. Форе, с другой - такая образно-содержательная корректировка отвечает более сдержанному и прагматичному отношению к смерти в англиканстве, что обусловило отказ от таинства смерти и погребе- 
ния и более чем скромную его обрядовую сторону. В наследование традиций англиканского богослужения используется и текст Псалма 43, который является одним из «похоронных предложений» «Книги общих молитв».

Реквием Дж. Раттера (1985) - крупнейшей фигуры в мире хоровой музыки Великобритании - является одним из самых известных и исполняемых в мире, в том числе и хором Одесской музыкальной академии. Это произведение, посвященное памяти отца композитора, многие считают лучшим сочинением Раттера. Примечательно, что Реквием очень популярен среди любительских групп молодых певцов, и его партитуры пользуются большим спросом в Великобритании и США. Раттер является не только композитором, но хоровым дирижером, редактором, аранжировщиком и продюсером звукозаписи, имеющим свой собственный лейбл (фирму звукозаписи - Collegium Records), который специализируется исключительно на церковной музыке. Его педагогическая деятельность связана с Клер-Колледжом в Кембридже, где он руководил также хором. В течение многих лет он является бессменным руководителем хорового коллектива «Кембриджские певцы» (основан в 1981). Раттер - почетный член Вестминстерского хорового колледжа и член Гильдии церковных музыкантов.

В Реквиеме органично переплетаются различные вокально-хоровые традиции: идущая от католического (Missa pro defunctis) и от протестантского богослужений (протестантские хоровые гимны, псалмы). В этом контексте примечателен тот факт, что Дж. Раттер в основном работает в жанрах церковной традиции, а рождественские песни и гимны - наиболее показательные для английской хоровой традиции жанры - часто определяют как основную «специализацию» композитора. Наследование своих национальных традиций хорового искусства и адаптация их к современным условиям бытования церковной музыки - вот центральная творческая и профессиональная установка композитора, снискавшего славу выдающегося мастера в международном хоровом сообществе.

Реквием написан для сопрано соло, смешанного хора и камерного оркестра; предусмотрена версия этого сочинения также с более «церковным колоритом» - с органом и инструментальным ансамблем, в котором преобладают духовые инструменты, что наследует традиции инструментального сопровождения богослужения в английских соборах со времен правления Эдуарда VI и Елизаветы. Также исполь- 
зована арфа, которая очень часто присутствует в профессиональной британской музыке, а истоки использования этого инструмента восходят к кельтской музыкальной традиции.

В семичастной композиции Реквиема в пяти использованы тексты латинской заупокойной мессы, в двух - тексты Псалмов 130 и 20 на английском языке (вторая и шестая части), которые присутствуют в англиканской «Книге общих молитв» в чине погребения. Так же, как и в Реквиеме Б. Чилкотта, здесь отсутствует «Dies irae», вместо которой композитором взят только фрагмент из этой части латинской заупокойной мессы - «Pie Jesu». В отличие от Б. Чилкотта, Дж. Раттер озвучивает тексты псалмов не исключительно хоровой фактурой, а «расцвечивая» их тембрально. Так, «Из глубины взывая....» (вторая часть) звучит у хора в контрапункте с выразительной декламационной мелодией виолончели на фоне гармонической педали оркестра, которая сменяется мелодическими вкраплениями гобоя. Выделение тембров гобоя и виолончели, которые воспринимаются в смысловом контексте стиха псалма как голоса «низа» и «верха» (человека и Бога), придают аскетичному звучанию хора эмоциональные оттенки, сообщают ему лирический тон высказывания. В шестой части («Господь пастырь мой...) текст псалма, на который традиционно в англиканстве писался гимн, поручен солирующему сопрано в сопровождении органа или фортепиано, а во вступлении к этой части звучит выразительный монолог гобоя с арфовыми переливами (ансамблевое звучание органа, гобоя и арфы - весьма специфическое явление, которое специально оговаривается Э. Уилсоном-Диксоном в связи с инструментальной составляющей английской богослужебной музыки [6]).

Как видим, англиканское наследие литургической хоровой практики обусловило специфику инструментального мышления композитора, определившего стилевой облик данного сочинения. И несмотря на то обстоятельство, что сам Дж. Раттер не считает себя религиозным человеком в привычном понимании, его высочайший профессионализм позволил творчески реализовать его принадлежность к культурной традиции, так или иначе повлиявшей на индивидуальное композиторское представление о жанровой стилистике заупокойной мессы.

Фигура Дж. Тавенера примечательна повышенным вниманием композитора к жанру реквиема, им написаны четыре опуса в этом жанре: Celtic Requiem (Кельтский реквием, 1969), Little Requiem for Father Malachy Lynch (Маленький реквием для отца Малахи Линч) 
для смешанного хора, струнных, трубы, и органа (1972), Реквием Ахматовой для сопрано, баса и оркестра (1980) и Реквиема для солистов, хора, виолончели и оркестра (2007).

Если стилистика сочинений Дж. Раттера и Б. Чилкотта складывается в результате синтеза традиций римо-католической и англиканской заупокойной службы, то в случае с Дж. Тавенером реквием как классический западноевропейский литургический жанр переживает значительные трансформации. Это связано с уникальным в истории британской музыки случаем обрашения к иной религиозной традиции: Дж. Тавенер - единственный в Британии композитор, принявший православие (его крестил в 1977 году митрополит Антоний Сурожский). Такая принципиальная межкультурная установка - декларация духовно-культурной ориентации на православие - обусловила и специфику стилистического облика его реквиемов, несовместимого со своей национальной традицией (кроме «Кельтского реквиема», написанного до 1977 года).

О главном влиянии на творчество Дж. Тавенера лучше всего сказал он сам: «Возможно, что тот факт, что я принял православие, необычайно важен, как и то, что моя музыка вдохновлена православием. С его помощью я могут достучаться до сердца англичан способом, о котором они не помышляли и с которым никогда не соприкасались» $[2$, c. 2]. Композитор обрел стилистическую и художественную опору в старинном знаменном распеве - разновидности древнерусского церковного пения. Феномену Дж. Тавенера можно дать вполне логичное объяснение, исходя из исторических путей развития английской культуры в целом. Истоки интереса Дж. Тавенера, воспитанного в пресвитерианской вере, к русской культуре можно объяснить известным моментом в истории Англии: речь идет о знаменитом Оксфордском движении, которое к середине XIX века заметно актуализировало интерес англиканства к восточной церкви.

Одним из ярких и показательных для стиля Дж. Тавенера является «Реквием Ахматовой», в основу которого положен оригинальный русский текст русского поэта. Известное содержание поэмы А. Ахматовой, связанное с трагическим периодом в истории России (сталинские репрессии), безусловно отвечает жанровой идее реквиема. Однако, используя текст Ахматовой в качестве основы своего сочинения, композитор «урезает» наличие литургического текста, который является неотъемлемым компонентом сакральности [3]. Дж. Тавенер рассматривает текст Ахматовой и саму его идею как некую «...медита- 
цию на смерть и глубоко русские качества, разделяемые традицией...» [2]. Традиция, о которой говорит композитор, представлена в его сочинении текстовыми фрагментами из православных служб - отпевания, Великой Пятницы и Светлого Воскресения. Эти тексты поручены басу, что соответствует тембровым предпочтениям православной певческой традиции; ахматовский текст звучит у сопрано - экспрессивно и максимально приближенно к русской музыкальной интонации за счет жанровой определенности тематизма. У сопрано в диалоге со струнными и перкуссией представлены распевный мелодизм русской песни, интонации причета и плача, медитативная мерность колыбельной и т. п. Этот интонационный «набор» противопоставлен аскетичным и кратким фразам сакральных текстов баса (молитвы об усопших), которые обрамлены символичным звучанием колоколов и перкуссии (похоронный звон).

Обобщая наши рассуждения, отмечаем, что индивидуальный стиль композиторов 1970-2000 годов формировался в совершенно ином национально-культурном контексте, нежели творчество их выдающегося предшественника Б. Бриттена. Их творчество ориентировано на «иные» языки музыкальной выразительности и во многом - на «чистое», без академического интеллектуализма, возрождение национальных традиций, а также на актуальную с последней четверти прошлого века эстетику «новой сакральности». Если понимать сакральность традиционно, как «атрибут общения человека как члена христианского сообщества с Трансцендентным» [3, 103], то интерес современных композиторов Великобритании к литургическому жанру заупокойной мессы объясним с точки зрения магистральных стилевых тенденций музыкального искусства последних десятилетий. Если же рассматривать реквиемы Б. Чилкотта, Дж. Раттера и Дж. Тавенера в контексте художественно-эстетическом, а не в религиозном, то сочинения демонстрируют характерные черты «новой сакральности» как специального направления музыкального творчества (обращение к литургическому жанру, использование в нем канонических литургических текстов, ориентация на концертное исполнение).

Также необходимо отметить, что Реквиемы Дж. Раттера и Б. Чилкотта среди профессиональных музыкантов иногда могут расцениваться как «простые» и «легкие»: действительно, в сравнении с хоровыми полотнами композиторов-классиков эти сочинения могут показаться несколько облегченными и упрощенными. Однако этому 
факту есть объяснение, которое напрямую определено национальными традициями хоровой британской музыки и ее генезисом, связанным с народно-фольклорной практикой. «Значительно раньше, чем в других европейских странах, в Англии наблюдается тесная взаимосвязь народного и профессионального творчества, которая установилась еще в эпоху Ренессанса», - пишет Л. Г. Ковнацкая [4, 10]. Подобные сведения, но в более кратком варианте содержатся и в «Музыкальной энциклопедии» [8]. Эта взаимосвязь во многом определила специфику английской хоровой церковной музыки ранних эпох, так как народная песня часто являлась ее музыкально-тематической основой, а приемы развития музыкального материала опирались на хоровую манеру исполнения, характерную для фольклорных жанров (раунд, кэтч, кэрол и т. п.).

С другой стороны, явная «упрощенность» музыкального языка реквиемов современных композиторов наследует стиль англиканского пения, который сформировался в результате довольно радикальных реформ богослужебной практики в Англии в XVI-XVII столетиях. Рекомендации королевской власти в XVI веке по изменению стиля церковной музыки были направлены прежде всего на ясность и доступность англоязычного текста обычному прихожанину: было отменено пение латинских антифонов, сопровождение органа и уменьшен состав хора. И главное - хор должен петь так, «...чтобы каждому слогу соответствовала ясная и отчетливая нота...» $[6,93]$. В основе англиканского хорала - силлабическая аккордовая вертикаль, исполняемая мужскими голосами, a cappella либо в сопровождении органа.

Выводы. Таким образом, жанровая стилистика рассмотренных Реквиемов Б. Чилкотта, Дж. Раттера и Дж. Тавенера формируется на основе совмещения различных национальных традиций заупокойной службы - римо-католической, англиканской (Раттер и Чилкотт) и православной (Тавенер). Различия этих традиций реализуются в этих сочинениях на таких уровнях: язык текстовой основы реквиема (латинский, английский, русский); использование канонического литургического и авторского поэтического текста на языке оригинала текста (частей римо-католической заупокойной мессы, псалмов из чина погребения «Книги общих молитв» и православной заупокойной службы, поэзии А. Ахматовой); состав инструментального сопровождения (орган, ансамбль деревянных духовых, колокола); жанровая окрашенность вокального тематизма. 


\section{СПИСОК ЛИТЕРАТУРЫ}

1. Ерохин В. Н. Английское католическое сообщество в XVI - первой половине XVII века в современной британской историографии: монография. Нижневартовск : Издательство Нижневартовского гуманитарного университета, 2012. $195 \mathrm{c}$.

2. Жилкин С. В духе времени: Джон Тавенер и его академическая музыка [Электронный ресурс]. Режим доступа: http://www.interviewrussia.ru/music/vduhe-vremeni-dzhon-tavener-i-ego-akademicheskaya-muzyka

3. Зосим О. Західноєвропейська богослужбова музика нового часу у вимірах нової сакральності. Мистецтвознавиі записки. Київ : НАКККіМ, 2015. Вып. 28. С. 103-110.

4. Ковнацкая Л. Г. Английская музыка XX века (истоки и этапы развития): очерки. М.: Советский композитор, 1986. 216 с.

5. Назайкинский Е. Стиль и жанр в музыке. М. : ВЛАДОС, 2003. 248 с.

6. Уилсон-Диксон Э. История христианской музыки : [пер. с англ.]. М. : Мирт, 2001. 428 с.

7. Холопова В. Н. Музыка как вид искусства : учебное пособие. СПб. : Лань, 2000. 320 c.

8. Шнеерсон Г. М. Английская музыка. Музыкальная энциклопедия : в 6 томах. М. : Советская энциклопедия; Советская музыка, 1973. Т. 1. С. 147-162.

\section{REFERENCES}

1. Erokhin, V. (2012). English Catholic community in the XVI - first half of the XVII century in modern British historiography. Monography. Nizhnevartovsk: Publishing house of Nizhnevartovsk Humanitarian University, 2012. [in Russian].

2. Zhilkin, S. (2011). In the spirit of the times: John Tavener and his academic music. Retrieved from: http://www.interviewrussia.ru/music/v-duhe-vremeni-dzhon-tavener-i-ego-akademicheskaya-muzyka [in Russian].

3. Zosim, O. (2015). Western European liturgical music of the new time in the dimensions of the new sacredness. The art critic's notes. Vol. 28. Kyiv, 2015 [in Ukranian].

4. Kovnatskaya, L. (1986). English music of the twentieth century (sources and stages of development): Essays. Moscow : Soviet composer [in Russian].

5. Nazaikinsky, E. (2003). Style and genre in music. M.: VLADOS [in Russian].

6. Wilson-Dickson, E. (2001). History of Christian Music. St. Petersburg: Mirt [in Russian].

7. Kholopova, V. (2000). Music as an art form: a textbook. St. Petersburg : Lan [in Russian].

8. Shneerson, G. (1973). English music. The musical encyclopedia. In 6 volumes. Moscow: Soviet Encyclopedia; Soviet music, 1973. Vol. 1 [in Russian]. 